\title{
REKONSTRUKSI BENTUK DAN FUNGSI STRUKTUR SUMUR PUTARAN PADA TAMBANG BATU BARA ORANJE NASSAU PENGARON
}

\section{THE FORM AND FUNCTION RECONSTRUCTION OF WELL STRUCTURE AT ORANJE NASSAU PENGARON COAL MINING}

\author{
Ulce Oktrivia dan Nugroho Nur Susanto
}

\author{
Balai Arkeologi Kalimantan Selatan, Jl. Gotong Royong II,RT 03/06 Banjarbaru 70711, Kalimantan Selatan \\ email : ulce.oktrivia@kemdikbud.go.id; nugroho.nur@kemdikbud.go.id
}

\begin{abstract}
Abstrak.Sumur Putaran adalah sebutan masyarakat untuk struktur bata yang terletak di Kecamatan Pengaron, Kabupaten Banjar. Struktur ini diduga merupakan sebuah bangunan yang tersisa dari tambang batu bara Oranje Nassau Pengaron. Penelitian yang telah dilakukan di lokasi ini belum dapat menjawab secara pasti bentuk asli dan fungsi dari struktur ini pada masa lalu. Berdasarkan hal tersebut, tulisan ini bertujuan untuk mengetahui bentuk dan fungsi struktur Sumur Putaran. Tambang batu bara pada umumnya memiliki beberapa bangunan utama, yaitu sebuah kantor, rumah sakit, dapur, dan rumah pekerja. Selain itu, untuk tambang bawah tanah, pada umumnya juga dilengkapi dengan kipas berukuran besar yang berfungsi mengatur sirkulasi oksigen untuk pernapasan bagi pekerja dan mengurangi efek berbahaya akibat ledakan. Pemahaman sejarah batu bara Oranje Nassau, sangat penting dan strategis. Hal ini tidak saja terkait dengan teknologi yang diterapkan, namun menyangkut juga pada hegemoni dan keberlangsungan Kesultanan Banjar. Tulisan ini menggunakan metode deskriptif-komparatif. Data di lapangan akan dibandingkan dengan hasil penelusuran pustaka berupa arsip, foto, dan gambar. Penerapan metode ini menghasilkan asumsi bahwa terdapat beberapa fungsi bangunan yang ada di struktur Sumur Putaran. Fungsi yang pertama adalah sebagai rumah kipas untuk ventilasi, fungsi yang kedua sebagai rumah mesin, dan yang ketiga sebagai derek atau crane untuk mengangkat batu bara atau manusia dari dalam tambang yang terletak di bawah tanah.
\end{abstract}

Kata kunci: struktur, Sumur Putaran, Oranje Nassau, Pengaron, tambang, batu bara

\begin{abstract}
Sumur Putaran' is local people predicate for brick structure located in District Pengaron, Banjar Regency. The structure was allegedly as coal mining remnant, Oranje Nassau Pengaron. Research has been done in this location still can not answer the original form and function of the structure. Therefore, this paper aims to determine the shape and function of the "Sumur Putaran" structure. Generally, coal mining has several main building such as an office, hospital, kitchen, collier barracks. Underground mining is also equipped with a large-sized fan that serves to regulate the circulation of oxygen for coalman breathing and to reduce the harmful effects of blast. Understanding the history of coal mining Oranje Nassau is a very important and strategic. This is not only related to the applied technology, but also the hegemony and sustainability of the Banjarese Sultanate. This paper used a descriptive-comparative method. The data in the field were compared with the literature search results in the form of archives, photographs and drawings. The application of this method resulted in the assumption that there are some functions of existing buildings in "Sumur Putaran". The functions are as home ventilation fan, home machine, and a crane to lift coal or human from basement.
\end{abstract}

Keywords: structure, Sumur Putaran, Oranje Nassau, Pengaron, mining, coal 


\section{PENDAHULUAN}

Sumur Putaran adalah salah satu bangunan yang masih tersisa dari aktivitas tambang batu bara Oranje Nassau di Pengaron. Sumur Putaran merupakan istilah lokal masyarakat Pengaron. Istilah ini muncul karena terdapat dua lubang berbentuk persegi dan benda berbentuk mirip kipas yang saat ini sudah tidak ada lagi. Istilah ini kemudian menjadi kebiasaan bagi masyarakat Pengaron. Penelitian mengenai fungsi dan gambaran umum objek ini sangat penting mengingat Oranje Nassau adalah tambang batu bara awal di Kalimantan, bahkan di Indonesia. Saat ini, kondisi Sumur Putaran sudah tidak utuh lagi dan telah banyak bagian yang mengalami kerapuhan. Selain karena usia, aktivitas pengambilan bata dan besi di lokasi yang merupakan bagian dari bangunan Sumur Putaran, menyebabkan semakin rusaknya struktur. Pada saat ini yang tersisa dari Sumur Putaran hanya struktur bata, yang masih terlihat kokoh menjulang tetapi tidak utuh lagi.

Secara astronomis struktur Sumur Putaran terletak pada koordinat $03^{\circ} 18^{\prime} 17,0^{\prime \prime}$ Lintang Selatan dan $115^{\circ} 06^{\prime} 17,79 "$ Bujur Timur. Secara administratif struktur bangunan Sumur Putaran terletak di Desa Pengaron, Kecamatan Pengaron, Kabupaten Banjar, Provinsi Kalimantan Selatan. Posisi geografis Sumur Putaran terletak di sebelah timur Gunung Pagaran dan tidak jauh dari Sungai Maniapun Kecil. Menurut informasi tetua masyarakat, bahwa dahulu pada struktur dinding bata terdapat benda semacam kipas yang berukuran besar. Benda seperti kipas ini bilah atau rotornya masih dapat diputar dengan tangan. Hal demikian masih dapat dilihat sekitar tahun 1965-an (Tim Peneliti 2012: 29).

Sejarah mencatat aktivitas penambangan batu bara di Indonesia sudah mulai dilakukan pada tahun 1846. Tambang batu bara pertama terletak di Sungai Batu Api yang berjarak sekitar $4 \mathrm{~km}$ dari Sungai Riam Kanan, tidak jauh dari Lokpinang dan Gunung Batu Berbaris (Posewitz 1892: 27). Lebih lanjut dilaporkan, bahwa kegiatan eksploitasi batu bara di Sungai Batu Api dilakukan oleh etnis Tionghoa. Namun baru dua tahun tambang beroperasi, pada bulan Mei 1847, tambang ini ditutup. Penutupan tambang disebabkan karena banyak pekerja yang sakit. Selain itu, lokasinya juga tidak cocok untuk tambang batu bara, karena jarak dari pelabuhan di Banjarmasin terlalu jauh, sedangkan sungainya dangkal dan banyak jeram. Selama dua tahun beroperasi, tambang ini hanya menghasilkan 500.000 lbs batu bara (Posewitz 1892: 462).

Sumber arsip lainnya menyebutkan bahwa aktivitas pertambangan batu bara juga telah dirintis di daerah Riam. Aktivitas pertambangan batu bara ini dipimpin oleh C. Lomblen. Dari dokumen surat-menyurat, aktivitas persiapan dan operasional tambang telah berlangsung sekitar tahun 1847 (Arsipnas, Borneo Z.O No Inv. 54/1 dan 54/2). Berdasarkan informasi ini, tampaknya kedua lokasi tambang tersebut terletak tidak berjauhan. Kedua tambang batu bara tersebut terletak di Kabupaten Banjar, Provinsi Kalimantan Selatan.

Bersamaan dengan penemuan kandungan batu bara di Sungai Batu Api, Schwaner juga menemukan kandungan batu bara di Sungai Riam Kiwa (Posewitz 1892: 271). Lokasi kandungan batu bara tersebut terletak di Kecamatan Pengaron saat ini. Pengaron lebih dikenal sebagai lokasi pertama meletusnya Perang Banjar yang terjadi pada tahun 1859. Sebelum meletusnya perang Banjar, Pengaron adalah saksi mata berdirinya tambang batu bara di Indonesia yang dikelola oleh pemerintah kolonial. Tambang batu bara tersebut diresmikan oleh Gubernur Jendral J.J. Rochussen pada tahun 1849 dan diberi nama Oranje Nassau.

Seratus enam puluh tiga tahun dari peresmian tambang Oranje Nassau atau tepatnya tahun 2012, Balai Arkeologi Banjarmasin (sekarang berubah nama menjadi Balai Arkeologi Kalimantan Selatan) yang bekerjasama dengan Dinas Kebudayaan Pariwisata Pemuda dan Olahraga melakukan penelitian yang kedua kalinya di lokasi tambang Oranje Nassau. Dari penelitian ini, dapat diketahui sisa bangunan tambang Oranje Nassau yang masih tampak sampai dengan saat ini. Sisa bangunan tambang yang masih dapat terlihat adalah sebuah struktur bangunan bata yang kondisinya sudah mulai hancur, makam Belanda, dan beberapa pintu masuk lorong tambang yang 
sudah tertutup reruntuhan tanah (Tim Peneliti 2012: 17-21; 28-30). Selain itu, juga terdapat fitur-fitur lubang yang ukurannya bervariasi dari ukuran $1 \mathrm{x}$ 1 meter hingga lebih dari $2 \times 2$ meter yang berjumlah 65 buah. Fitur lubang ini terletak di punggung dan lereng Gunung Pagaran. Berdasarkan hasil ekskavasi di sekitar struktur bangunan bata, ditemukan juga beberapa artefak berupa bata, fragmen genteng, paku, roda dari besi, fragmen rel besi, kayu bekas tumpuan, fragmen botol, tutup botol, dan mata uang (Tim Peneliti 2012: 44-48).

Sumur Putaran adalah bangunan monumental terpenting yang masih tersisa hingga sekarang. Penelitian yang dilakukan oleh Balai Arkeologi Kalimantan Selatan pada tahun 2012 belum bisa menjawab bagaimana bentuk asli dan fungsi bangunan ini. Selain karena kondisinya yang sudah tidak utuh lagi, banyak bagian yang telah rusak, juga disebabkan sangat sedikitnya data artefaktual yang dapat digunakan untuk menerangkan bentuk dan fungsi bangunan. Informasi yang diperoleh dari masyarakat, tidak memadai dan tidak ada saksi hidup yang dapat memberikan informasi detail struktur bata ini, sedangkan informasi dari masyarakat yang tinggal di sekitar Sumur Putaran masih perlu diuji kebenarannya.

Keberadaan data arkeologi yang terkait dengan tambang batu bara Oranje Nassau sangatlah penting. Keberadaan tambang batu bara Oranje Nassau menunjukkan bahwa kekayaan alam Nusantara sangat melimpah. Tambang Oranje Nassau juga dipandang sangat bernilai strategis oleh pemerintah kolonial Belanda dibuktikan dengan hadirnya Gubernur Jendral J.J. Rochussen untuk meresmikan beroperasinya tambang tersebut. Secara de facto keberadaan tambang Oranje Nassau berdampak pada sisi politis maupun dari segi teknologinya. Secara politis memperlihatkan tambang ini bukan sematamata usaha dari pemerintah kolonial Belanda, tetapi ada campur tangan dan permainan intrik politik yang sangat kentara. Ratu Anom Bumi Kencana selain berperan dalam menyewakan tanah, yang mendapat ganti f. 140,- untuk setiap tonnya, juga berperan mempersiapkan pekerjapekerja, yang berstatus sebagai pandeling dan pekerja budak (Ahyat 2012: 113-114). Sejauh mana unsur pekerja dan teknologi berperan tentu memerlukan gambaran berdasarkan data yang kuat. Berdasarkan latar belakang ini, maka permasalahan yang diajukan adalah

1. Bagaimanakah bentuk asli bangunan Sumur Putaran?

2. Apakah fungsi Sumur Putaran?

Menurut Kamus Besar Bahasa Indonesia, rekonstruksi berarti pengembalian seperti semula dan penyusunan atau penggambaran kembali (Tim Penyusun 1995: 829). Bentuk memiliki arti yang lebih luas mengikuti kalimat di depan atau di belakang kata bentuk. Dalam karya tulis ini kata bentuk diartikan sebagai gambaran (Tim Penyusun 1995: 119).

Pada dasarnya, penelitian arkeologi tidak akan bisa menjawab fungsi dan bentuk sebuah struktur bangunan tanpa adanya data pustaka, data pembanding, dan informan kunci. Informasi mengenai keberadaan bangunan di tambang Oranje Nassau dapat diketahui dari buku karangan Dr. Theodor Posewitz yang berjudul Borneo its Geology and Mineral Resource. Dalam buku tersebut memang tidak secara langsung menyebut jenis atau fungsi bangunan, namun informasi mengenai jenis pekerjaaan atau profesi yang pernah ada di tambang Oranje Nassau dapat dijadikan asumsi awal terkait bangunan yang pernah ada di lokasi tambang ini.

Dari buku tersebut dapat diketahui profesi atau pekerjaan yang ada di tambang Oranje Nassau, yaitu satu orang administrator yang memimpin administrasi tambang, seorang pegawai administrasi, seorang kepala rumah sakit dan dapur, seorang kepala penjara, sipir, dan 12 orang mandor. Terdapat juga informasi jika para narapidana yang dipekerjakan di tambang memiliki ketrampilan dan berkelakuan baik, maka akan dipromosikan menjadi mandor, tukang kayu, tukang batu, perawat rumah sakit, dan pengawas depot batu bara.

Informasi lainnya menyebutkan bahwa terdapat beberapa jenis mesin yang ada di tambang Oranje Nassau. Mesin tersebut adalah hoisting machine, ventilator (guibal's), chain pump, dan steam pump (Posewitz 1892: 472). Mesin 
steam pump terletak di lorong tambang paling dasar, sedangkan hoisting machine, ventilator (guibal's), dan chain pump posisinya masih belum diketahui.

Dari informasi profesi pekerja tambang dapat diketahui kemungkinan jenis bangunan yang terdapat di tambang Oranje Nassau. Bangunan yang kemungkinan pernah ada di tambang Oranje Nassau adalah kantor administrasi, rumah sakit, dapur, dan penjara. Selain bangunan tersebut, kemungkinan juga terdapat bangunan untuk melindungi mesin dari panas dan hujan.

T.C. Cantril (1914: 14-18) menyebutkan bahwa teknologi eksplorasi underground semakin tertata sejak tahun 1808, lorong-lorong eksploitasi dilengkapi dengan ventilasi, lampu-lampu, dan drainase. John Buddle memperkenalkan sistem panel-panel atau ruang-ruang eksplorasi dalam sistem underground. Seiring dengan kedalaman yang ingin dicapai, maka diperkenalkan peralatan kipas untuk mendukung ventilasi udara, mengatur sirkulasi oksigen untuk pernapasan bagi pekerja dan mengurangi efek berbahaya akibat ledakan (Cantril 1914: 29; Susanto 2015: 196). J.J Wilkinson memperkenalkan prinsip-prinsip keselamatan kerja untuk mencegah kecelakaan kerja bagi buruh tambang batu bara, misalnya dengan memperkenalkan alat komunikasi dan lampu senter yang dipakai di kepala. Pada tahun 1837 William Fournees memperkenalkan kipas besar dan pada tahun 1844 mesin kipas besar ini diproduksi dengan ukuran dan kapasitas mendorong udara lebih besar (Cantril 1914: 31-3; Susanto 2015: 197).

Pemahaman sejarah batu bara Pengaron, terutama di Oranje Nassau, sangat penting dan strategis. Hal ini tidak semata-mata terkait dengan hal-hal teknis dan kemajuan teknologi, tetapi menyangkut hegemoni dan keberlangsungan Kesultanan Banjar (Saleh 1979: 14-15). Di sinilah untuk pertama kali Perang Banjar berkobar. Saat tambang diresmikan, aspek politik dan ekonomi sangat terkait di dalamnya. Proyek ini dapat dianggap prestisius, dapat dipandang maju dan modern pada zamannya (Lindblad 2012: 34-35)

\section{METODE}

Karya tulis ini disusun dengan teknik penelitian gabungan antara observasi objek, dengan melihat bukti-bukti material dan desk research. Artinya kegiatan pengumpulan data dilakukan di lapangan, sedangkan pemecahan masalah diselesaikan dengan membandingkan tinggalan yang ada, dengan berbagai literatur, informasi dan diperkaya dengan studi pustaka berupa arsip-arsip yang dibuat oleh Belanda. Cara ini ditempuh, khususnya untuk mendapatkan pemahaman tentang gambaran umum, bentuk, dan fungsi Sumur Putaran.

Karya tulis ini bersifat deskriptif dengan teknik komparatif. Menurut Andi Prastowo, penelitian komparatif adalah membandingkan faktor-faktor dari fenomena sejenis pada masa lampau (Prastowo 2014: 184). Dalam karya tulis ini, komparatif digunakan untuk membandingkan suatu objek yang ada pada masa dengan data pustaka berupa arsip dan dokumen foto atau gambar yang dibuat pada masa lalu. Data hasil penelitian Balai Arkeologi Kalimantan Selatan tahun 2012 dan 2014 akan dibandingkan dengan studi pustaka. Dengan metode membandingkan ini akan diperoleh deskripsi mengenai bentuk, fungsi, dan gambaran umum. Secara kronologis, jika permasalahan mengenai bentuk Sumur Putaran telah terjawab, maka langkah untuk mengetahui fungsi dari Sumur Putaran akan lebih mudah dijawab. Untuk mengetahui fungsi Sumur Putaran digunakan studi pustaka dengan menghadirkan gambar-gambar yang mirip dengan bentuk Sumur Putaran. Pustaka mengenai informasi atau gambar diprioritaskan pada bangunan tambang batu bara, terutama seperti Sumur Putaran.

\section{HASIL DAN PEMBAHASAN}

Keberadaan dan latar belakang pendirian tambang batu bara Oranje Nassau, di Pengaron dilandasi oleh semangat dan rasa percaya diri. $\mathrm{Hal}$ ini tercermin dari kemeriahan pesta 
peresmian yang berlangsung 13 hari, oleh J.J Rochossen di atas kapal (Lindblad 2012: 34). Lebih lanjut diterangkan bahwa tambang batu bara ini dapat dianggap modern di eranya. Seseorang untuk menelusuri terowongan yang ada memerlukan waktu berjam-jam. Walaupun demikian, kapasitas produksinya tergolong kecil (Lindblad 2012: 35). Sumur Putaran mendapat perhatian lebih, bukan saja karena peninggalan yang hingga kini masih bertahan, tetapi karena fungsinya yang sangat penting.

\section{Struktur Sumur Putaran}

Sumur Putaran secara administrasi terletak di Desa Pengaron, RT III, Kecamatan Pengaron, Kabupaten Banjar. Struktur ini memanjang dari arah barat daya ke timur laut, sedangkan arah hadap bangunan ini masih belum diketahui. Namun untuk mempermudah pendeskripsian Sumur Putaran ini maka untuk sementara ditetapkan arah hadap bangunan adalah barat daya.

Penggalian yang telah dilakukan oleh Balai Arkeologi Kalimantan Selatan berhasil menemukan dua kelompok struktur bangunan. Struktur bangunan tersebut disebut struktur $B$ atau struktur bangunan Sumur Putaran dan struktur C yang berbentuk persegi panjang, terletak di sebelah timur laut struktur B. Kedua struktur bangunan ini hanya berjarak 30 meter. Struktur bangunan $B$ atau disebut sebagian masyarakat sebagai Lubang Putaran atau Sumur Putaran

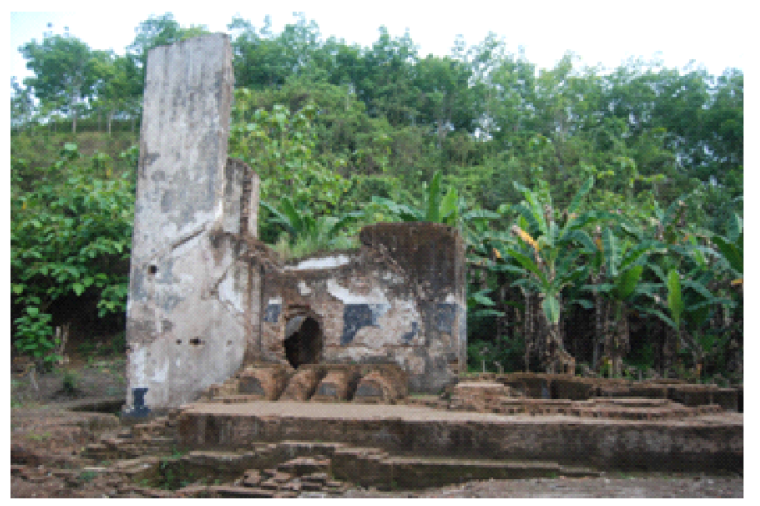

sumber: dok. Balai Arkeologi Kalimantan Selatan

Gambar 1. Kondisi struktur sumur putaran sebagian besar terletak di atas tanah, hanya sebagian kecil saja yang tertimbun tanah. Begitu juga dengan struktur $\mathrm{C}$, sebagian besar masih tampak di atas tanah meskipun hanya bagian fondasinya saja.

Struktur bangunan Sumur Putaran yang masih dapat dilihat sampai saat ini berbentuk persegi empat dengan bangunan berbentuk menara (lihat gambar 1). Struktur ini pada bagian dalamnya memiliki ruangan yang berbentuk lingkaran dengan diameter 5 meter dan tebalnya sekitar 1 meter. Ruangan berbentuk lingkaran ini pada bagian sebelah barat sudah berlubang. Lubang ini bukan pintu atau jendela, akan tetapi kemungkinan besar merupakan akibat dari kegiatan pengambilan bata atau besi yang terdapat pada struktur Sumur Putaran. Pada bagian sebelah timur terdapat pintu atau jendela yang bagian atapnya berbentuk setengah lingkaran dan bagian dasarnya telah runtuh. Menara yang terdapat pada struktur Sumur Putaran bagian dalamnya berlubang. Semakin ke bawah semakin kecil dan menyatu dengan ruangan berbentuk lingkaran. Pada bagian bawah menara ini terdapat pintu ke arah ruangan berbentuk lingkaran.

Struktur Sumur Putaran memiliki lima buah lorong (lihat gambar 2). Empat lorong terletak di sebelah kiri dan kanan bangunan Sumur Putaran. Lorong ini berukuran $1 \times 1$ meter memanjang dari arah barat daya ke timur laut. Satu lorong lainnya terletak di bawah bangunan Sumur Putaran. Lorong ini berbentuk $L$ yang dimulai dari bawah pintu ruangan berbentuk lingkaran yang lantainya telah runtuh menuju ke arah Sumur 1 . Selain lorong, di lokasi ini juga terdapat dua lubang. Lubang ini disebut Sumur 1 dan Sumur 2. Sumur 1 terletak di tengah empat lorong yang telah disebut di atas, sedangkan Sumur 2 berjarak 19 meter dari Sumur 1 ke arah barat daya. Sumur 1 berukuran 2,8 x 1,8 meter sedangkan Sumur 2 berukuran 2,8 $\times 2$ meter. Sampai dengan akhir penelitian, kedalaman kedua sumur ini belum diketahui.

Struktur C secara umum dapat dikatakan berbentuk persegi panjang dengan ukuran 10,4 $x 7,8$ meter. Struktur ini memanjang dari barat daya 


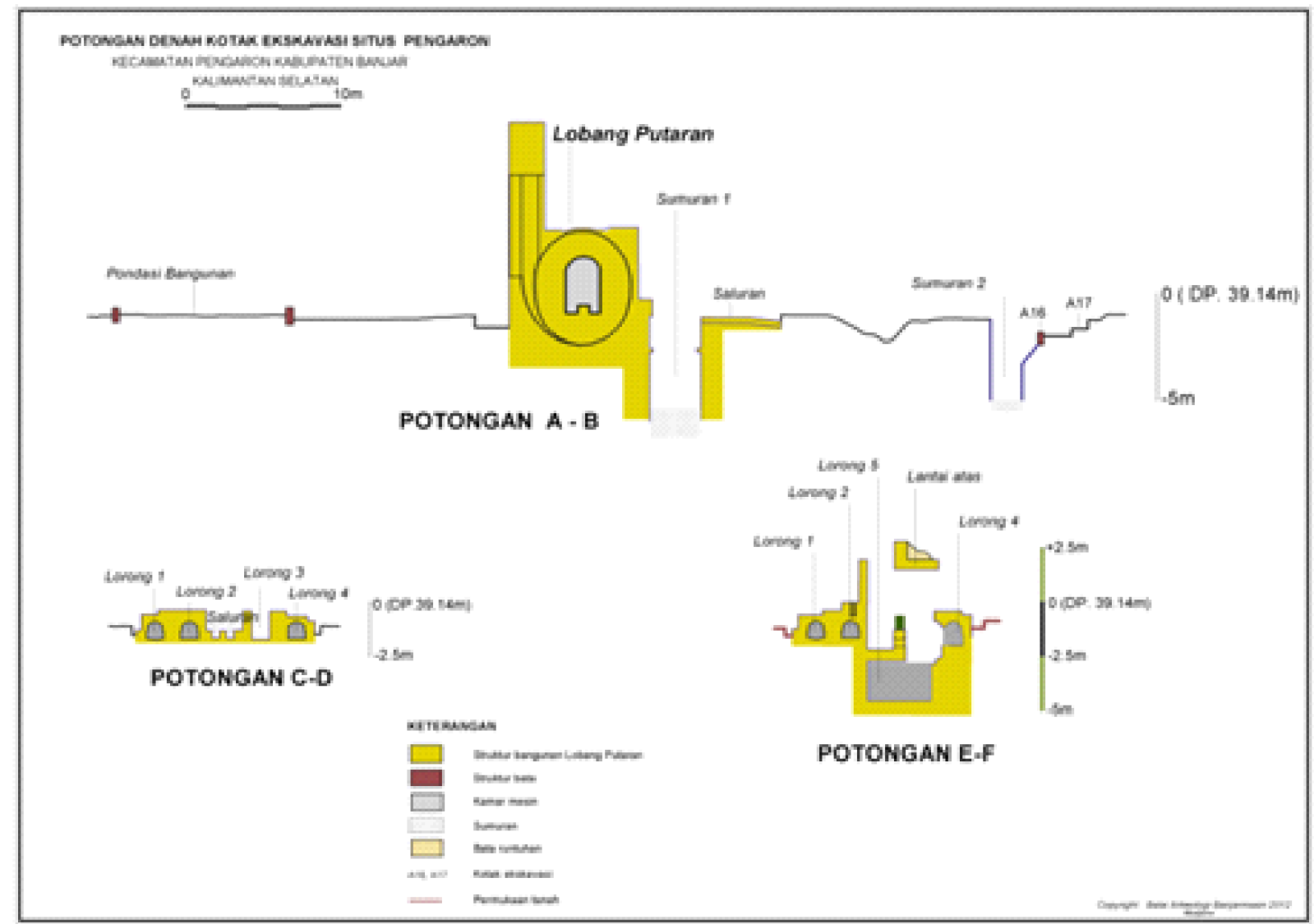

sumber: dok. Balai Arkeologi Kalimantan Selatan

Gambar 2. Penampang struktur Sumur Putaran

ke timur laut. Pada sisi barat daya dan sisi barat terdapat bagian yang tidak ditemukan strukturnya. Terdapat dua kemungkinan mengenai bagian yang tidak ditemukan strukturnya. Kemungkinan pertama adalah bagian ini adalah lokasi pintu sehingga tidak terdapat struktur di bagian ini. Kemungkinan kedua adalah struktur di tempat ini sudah hancur.

\section{Pengaron dalam Sumber Arsip}

Berdasarkan hasil penelusuran arsip foto dari koleksi KITLV terdapat empat gambar tentang Pengaron. Gambar pertama berjudul "Meeroever bij Pengaron, Borneo" (lihat gambar 3). Gambar ini merupakan sebuah foto yang menunjukkan perahu bercadik yang berada di tepian danau atau sungai di Pengaron.

Gambar ke dua berjudul "Pengaron" (lihat gambar 4). Gambar ini merupakan peta geologi Pengaron dan sekitarnya. Pada gambar ini tampak benteng Belanda yang terletak di Pengaron. Lokasi benteng Belanda ini ditandai dengan bendera merah putih biru. Selain lokasi benteng, juga terdapat gambaran sederhana Sumur Putaran.

Gambar ketiga berjudul "Pengaron" (lihat gambar 5). Di dalam gambar ini terdapat beberapa bangunan yang dikelilingi oleh pagar. Selain itu, juga terdapat tiang bendera lanskap di depan bangunan berupa sungai, yang diduga Sungai Riam Kiwa dan pegunungan atau bukit. Gambar ini diambil dari sebuah bukit.

Gambar yang terakhir berjudul "Kolenontginning te Pengaron: aan de rivier Riam Kiwa (diepbouw)" (lihat gambar 6). Terdapat tiga gambar berbeda dalam satu arsip ini. Gambar pertama terletak di bagian paling atas adalah gambar garis-garis vertikal horisontal bangunan dengan menara beratap, dan cerobong asap. Gambar ini tampaknya adalah denah lorong tambang. Gambar kedua merupakan kompleks 


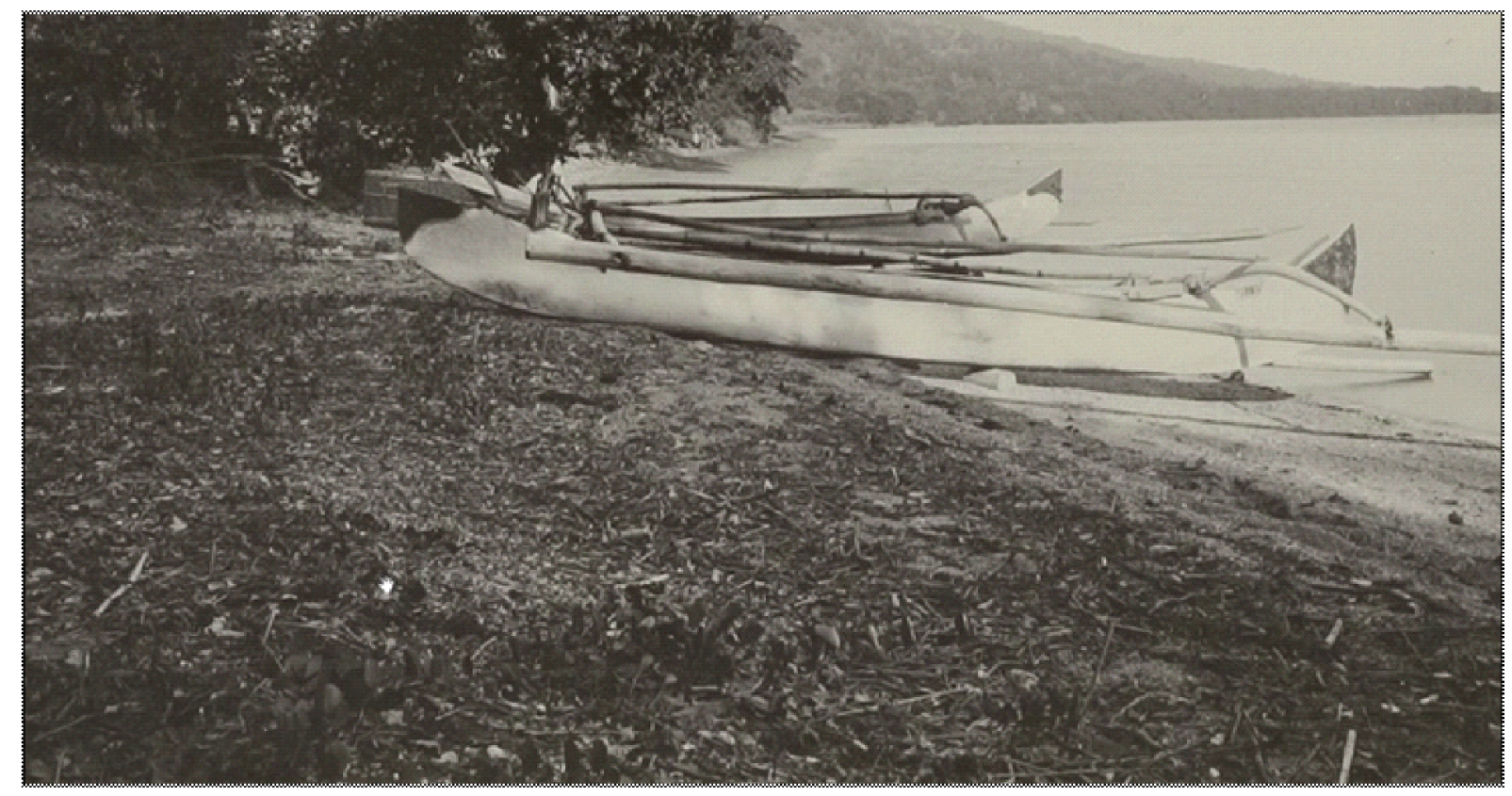

sumber: Circa 1900: tanpa halaman

Gambar 3. Meeroever bij Pengaron, Borneo(Tepi Danau Pengaron, Kalimantan)

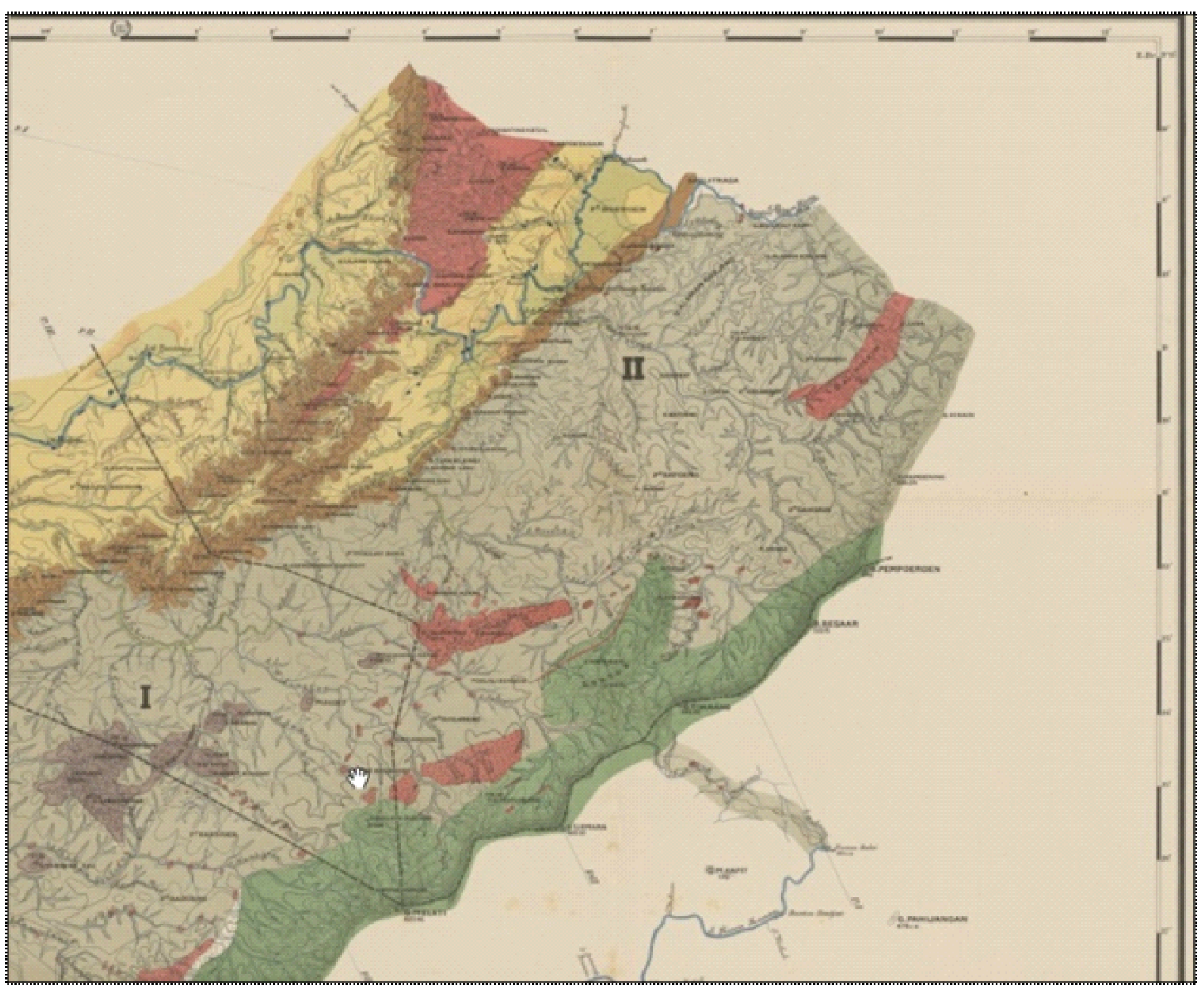

sumber: Czn 1893: tanpa halaman

Gambar 4. Pengaron

Rekonstruksi Bentuk dan Fungsi Struktur Sumur Putaran pada Tambang Batu Bara Oranje Nassau Pengaron Ulce Oktrivia dan Nugroho Nur Susanto (129-144) 


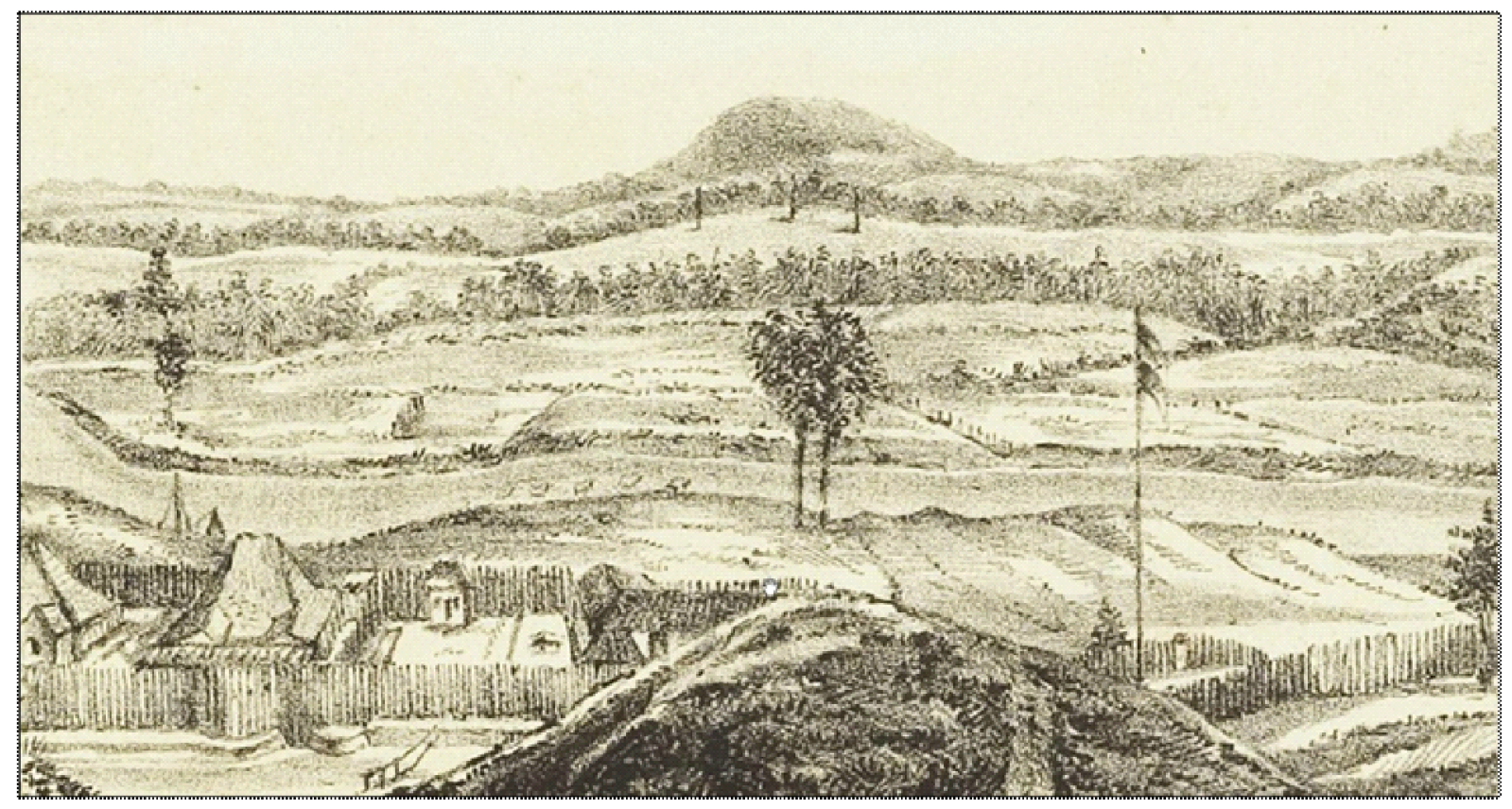

sumber: Dorp 1861: tanpa halaman

Gambar 5. Pengaron

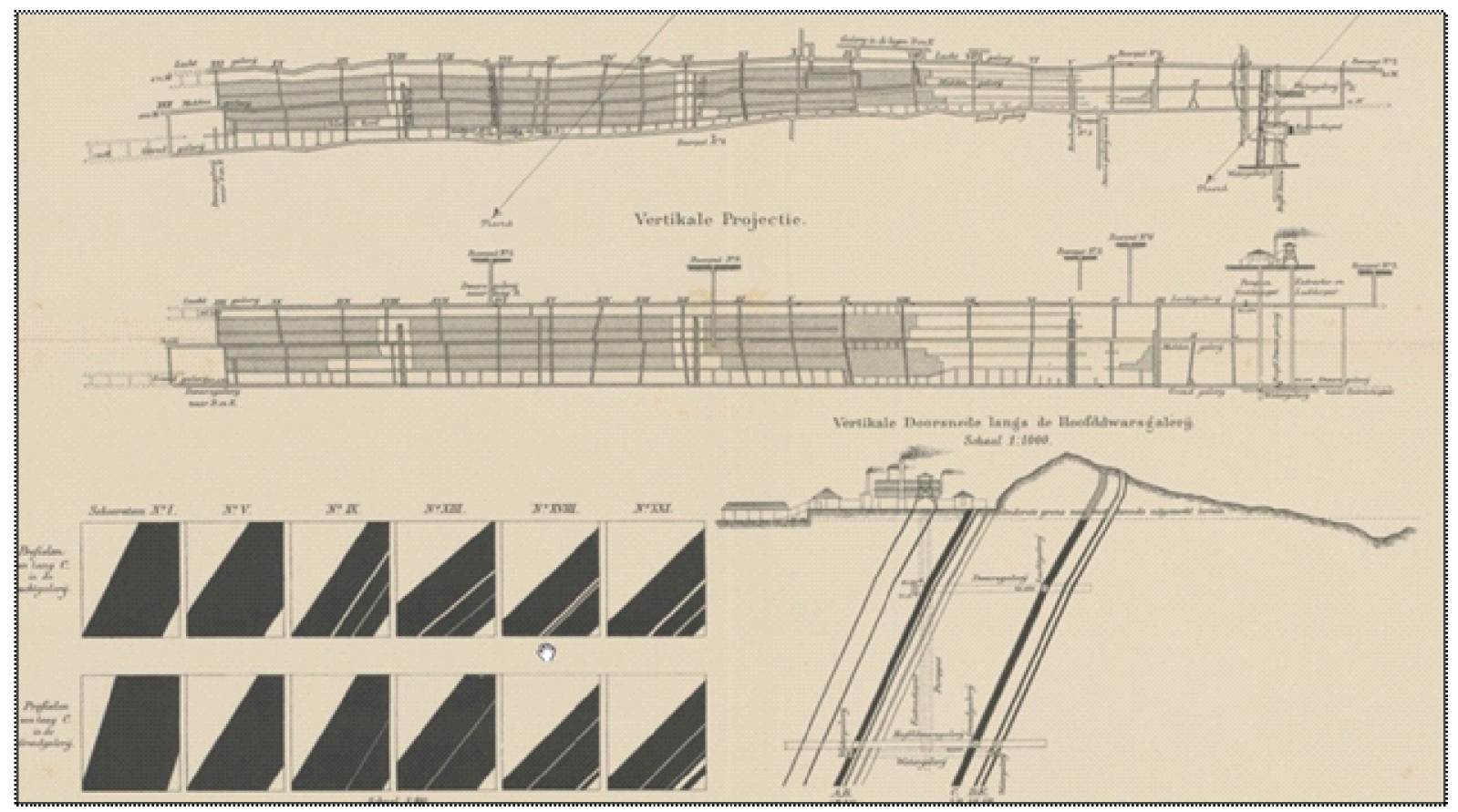

sumber: Hooze 1893: tanpa halaman

Gambar 6. Kolenontginning te Pengaron: aan de rivier Riam Kiwa diepbouw (Ekstraksi batu bara ke Pengaron, Sungai Riam Kiwa struktur bagian dalam) 
bangunan yang memiliki beberapa cerobong asap dan menara yang ditopang empat tiang. Pada bagian bawah bangunan terdapat garisgaris miring ke bawah dan garis vertikal horizontal. Keterangan yang terdapat pada garis vertikal antara lain adalah boorput, extractive en laderput, dan pomp en ventilatieput. Keterangan pada garis horizontal adalah luchtgallery, midden gallery, grond gallery, watergalery, dan dwars gallery. Gambar ini tampaknya merupakan pembesaran gambar bangunan pada gambar pertama. Gambar ketiga berupa garis garis tebal berwarna hitam. Gambar ini tampaknya merupakan perbesaran dari garis-garis miring yang ada di bawah bangunan gambar kedua.

Penelusuran lebih lanjut mengenai Sumur Putaran menghasilkan dua gambar. Kedua gambar ini diperoleh dari situs www.geheugenvannederland.nl. Gambar yang pertama berjudul "De plaats Pengaron" (lihat gambar 7). Gambar ini menunjukkan bangunan yang dikelilingi pagar. Pada gambar ini, tampak seluruh bangunan yang terletak di dalam pagar. Terdapat sebuah bendera dan enam orang manusia yang ada pada bagian depan gambar. Bagian latar belakang berupa jajaran pegunungan.

Gambar selanjutnya berjudul "Het dorp Pengaron" (lihat gambar 8). Pada gambar ini terdapat beberapa bangunan dengan dua menara dan satu menara lainnya yang mirip cerobong asap. Pada bagian depan gambar merupakan dataran berumput dengan dua orang manusia. Bagian latar belakang berupa beberapa bukit.

Penelusuran arsip selanjutnya diarahkan pada koleksi Arsip Nasional Republik Indonesia. Penelusuran ini berhasil menemukan satu gambar yang berjudul "Verticale Doorsnede en Aanzicht van het Machinegebouw der Mijn Oranje Nassau te Pengaron" (lihat gambar 9). Pada gambar ini terdapat satu bangunan dengan atap pelana. Di dalam bangunan ini terdapat satu ruangan berbentuk persegi yang terhubung dengan

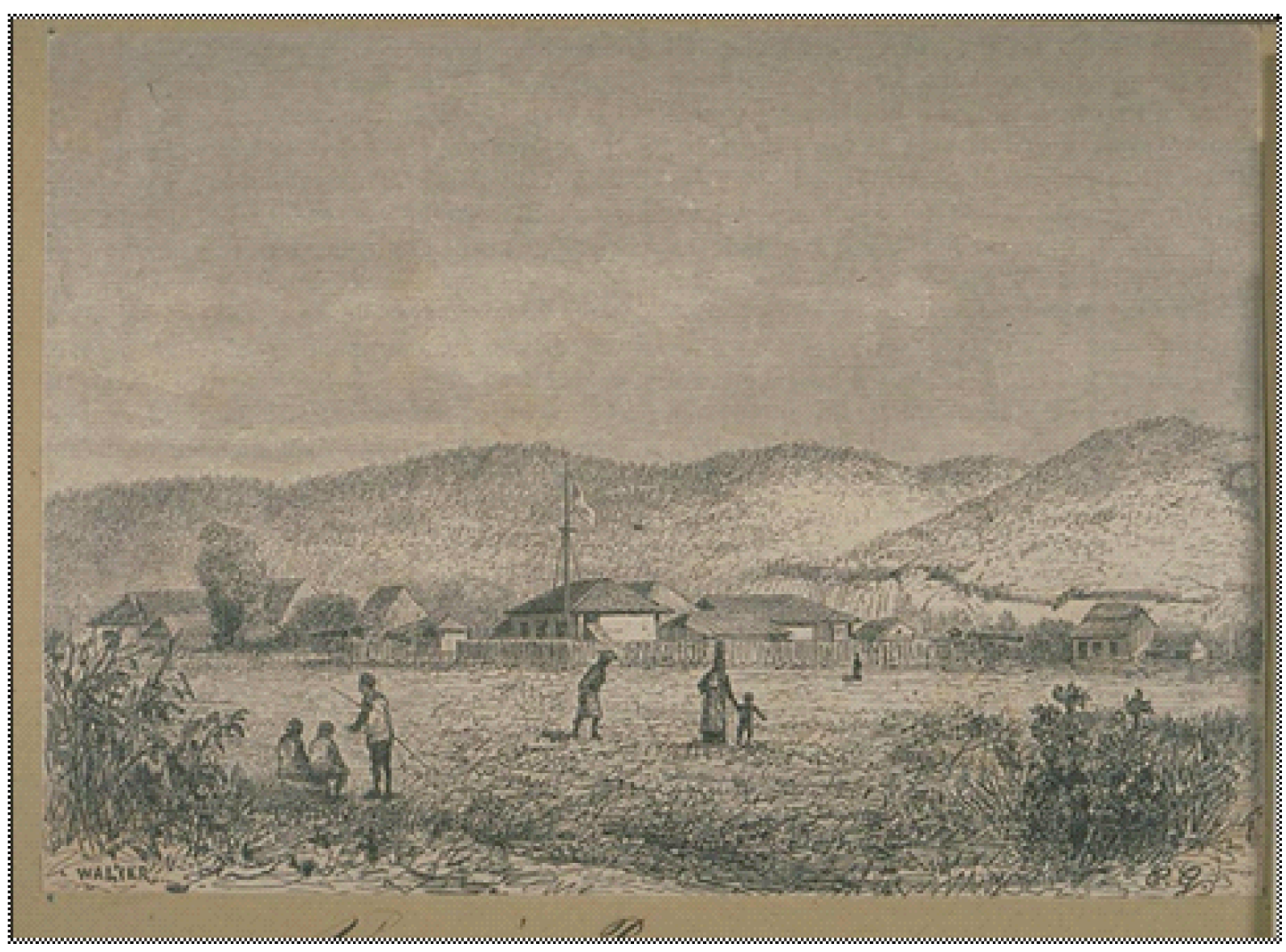

sumber: Tropenmuseum

Gambar 7. De plaats Pengaron (Suatu tempat di Pengaron) 


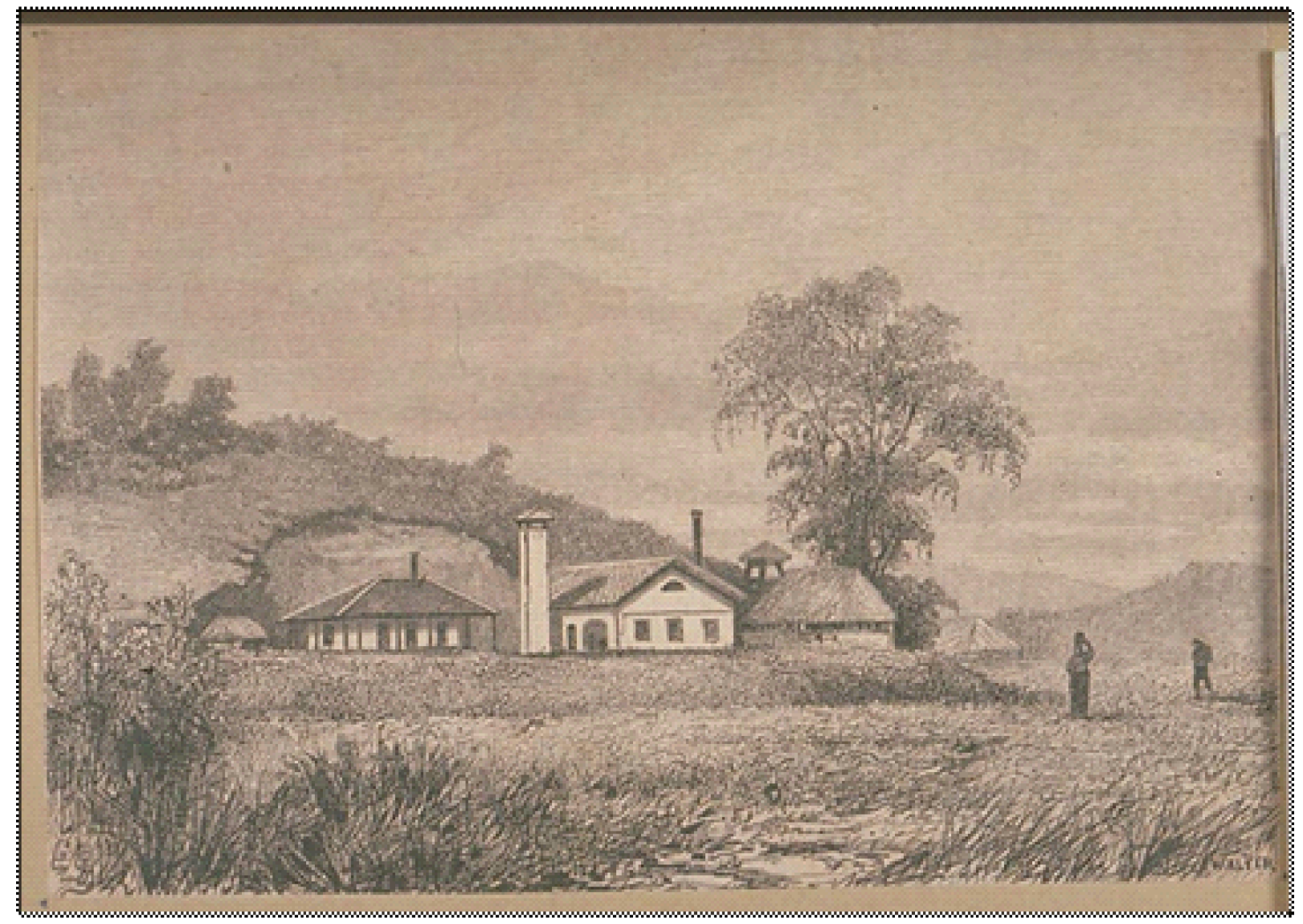

sumber: Tropenmuseum

Gambar 8. Het dorp Pengaron (Desa Pengaron)

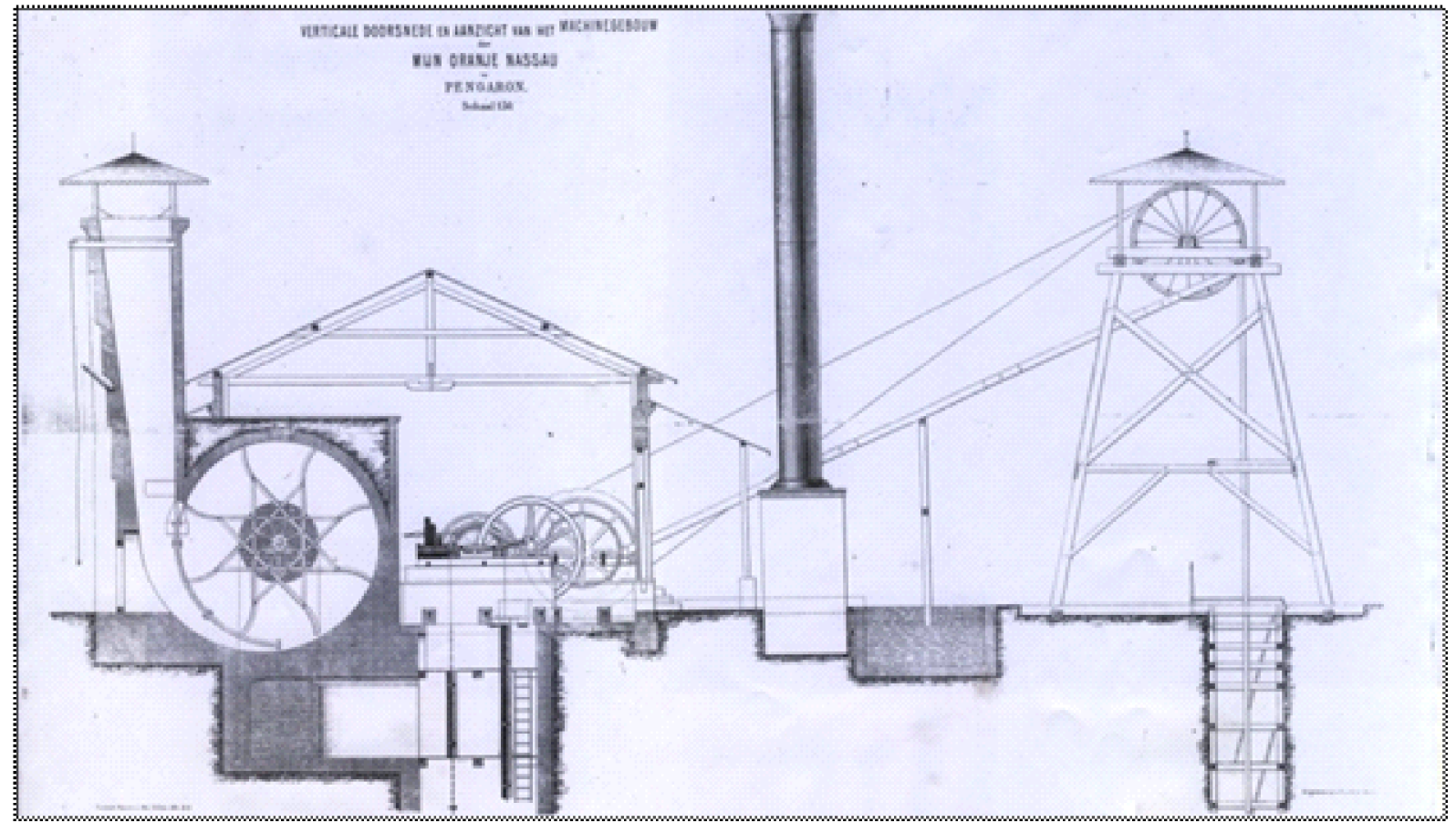

sumber: ANRI 1872 : tanpa halaman

Gambar 9. Verticale Doorsnede en Aanzicht van het Machinegebouw der Mijn Oranje Nassau te Pengaron (gambar penampang samping bangunan atau rumah mesin Oranje Nassau, Pengaron) 
menara. Di dalam ruangan persegi ini terdapat roda besar yang mirip seperti kipas. Pada bagian bawah ruangan persegi ini terdapat juga satu ruangan berbentuk persegi panjang. Di luar bangunan berbentuk persegi terdapat tiga roda dengan ukuran berbeda. Roda ini dihubungkan dengan tali menuju roda yang terletak pada menara. Pada bagian bawah ketiga roda ini terdapat lubang mirip sumur berbentuk persegi. Terdapat juga lubang berbentuk sumur di bawah menara beroda. Selain itu, juga terdapat satu cerobong asap.

\section{Komparatif Bentuk Sumur Putaran}

Dari delapan gambar hasil penelusuran berbagai sumber, gambar 3 tampaknya tidak memiliki kaitan dengan tambang Oranje Nassau dan Desa Pengaron. Masyarakat Pengaron dan Kalimantan umumnya tidak menggunakan perahu bercadik di sungai maupun danau. Perahu bercadik hanya digunakan di laut. Desa Pengaron terletak jauh dari laut.

Gambar 4 merupakan peta geologi yang di dalamnya termasuk wilayah Kecamatan Pengaron saat ini. Gambar ini memberikan informasi posisi benteng atau tangsi militer. Keyakinan ini didasari oleh perbandingan beberapa peta yang diproduksi Belanda. Dalam berbagai peta tersebut, gambar bendera identik dengan lokasi benteng atau tangsi militer. Hal ini telah dibuktikan pada peta Belanda di lokasi Nanga Pinoh, Melawi, dan Sintang, Kalimantan Barat. Bentuk benteng atau tangsi militer yang ada di Pengaron tampaknya identik dengan gambar 5 dan gambar 7. Dugaan ini dilatarbelakangi oleh adanya pagar yang mengelilingi kompleks bangunan. Dalam buku Sejarah Banjar disebutkan bahwa Pasukan Muning, Pasukan Riam Kiwa, dan dibantu buruh tambang Oranje Nassau yang berjumlah 665 orang berusaha mengurung benteng di Pengaron dari luar dengan harapan pasukan Belanda akan menyerah karena kekurangan bahan makanan (Sjarifuddin dkk. 2007: 281). Pengurungan ini tidak akan bisa terjadi tanpa adanya pagar di sekeliling Benteng Pengaron.
Gambar 6 dapat dipastikan sebagai tambang Oranje Nassau yang merupakan tambang bawah tanah. Gambar tersebut merupakan denah lorong tambang bawah tanah. Bangunan yang ada di dalam gambar tersebut kemungkinan besar adalah sumur putaran. Gambar bangunan tersebut dapat dibandingkan dengan gambar 8. Gambar 6 dan gambar 8 tampaknya memiliki kemiripan. Kemiripan tersebut tampak pada adanya cerobong asap meskipun jumlahnya berbeda dan juga adanya menara berkaki empat dengan atap limasan.

Kedua gambar ini tampaknya juga memiliki hubungan dengan gambar 9. Gambar 9 dapat dipastikan merupakan bentuk asli Sumur Putaran. Bagian menara yang terhubung dengan ruangan berbentuk persegi saat ini masih dapat dilihat di situs Pengaron. Lorong di bawah ruangan persegi lokasi roda yang mirip kipas sampai dengan saat ini masih dapat ditemukan. Dua lubang berbentuk persegi saat ini juga masih dapat ditemukan. Bangunan besar yang menutup ruang berbentuk persegi, cerobong asap, dan menara berkaki empat saat ini sudah tidak ditemukan lagi. Hal ini kemungkinan besar karena bangunan dan menara tersebut terbuat dari kayu. Meskipun demikian, keberadaan bangunan dapat dipastikan pernah ada di masa lalu. Hal ini diperkuat dengan adanya temuan lubang-lubang berbentuk persegi pada struktur Sumur Putaran yang dahulunya berfungsi untuk meletakkan tiang penyangga bangunan ini.

Struktur $C$ yang terletak tidak jauh dari struktur Sumur Putaran dapat juga dipastikan bentuknya dengan melihat gambar 9 . Bangunan ini berbentuk persegi panjang dengan atap limasan. Bangunan ini dikelilingi oleh teras. Terdapat tiga pintu di bagian depan dan jendela di bagian samping. Selain itu, juga terdapat satu cerobong asap. Gambar ini sesuai dengan bentuk dan lokasi struktur $\mathrm{C}$ sekarang.

Pada tahun 2014 penelitian lebih intensif dilakukan dengan metode ekskavasi. Di sekitar struktur Sumur Putaran ditemukan fragmen bata, genting, dan paku dengan berbagai ukuran. Struktur lantai di sisi kiri bangunan Sumur Putaran 

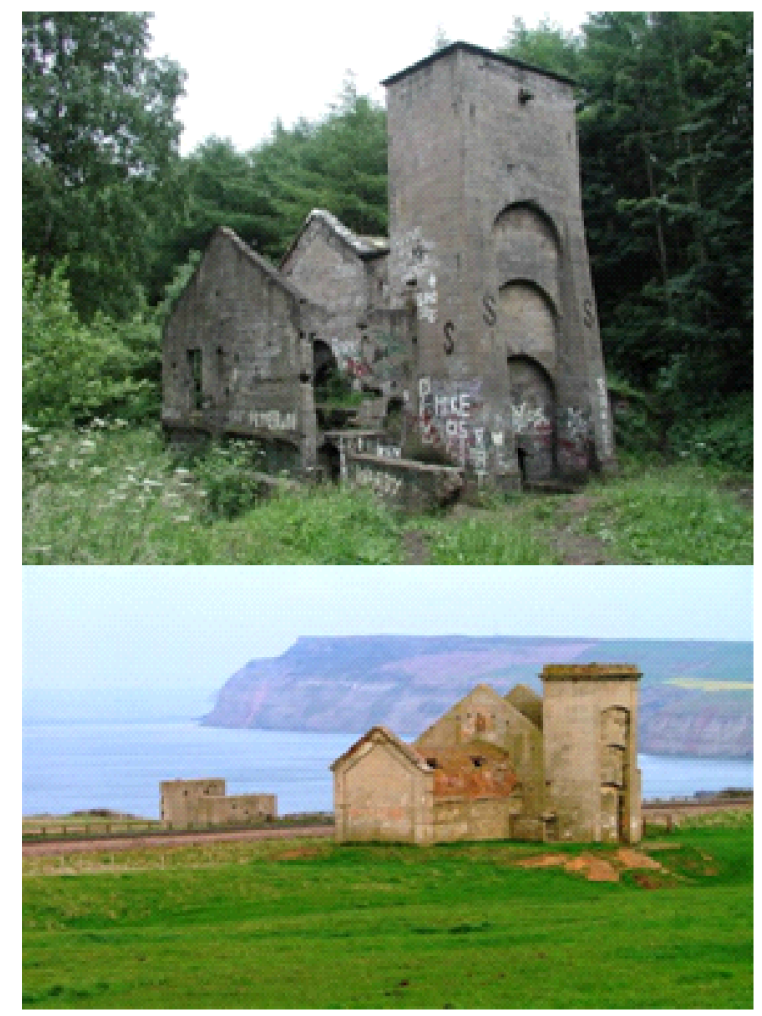

sumber: Pollard 2005 (gambar atas) Garratt 2006 (gambar bawah)

Gambar 10. Guibal Fan Eston (atas) dan Guibal Fan Huntcliff (bawah)

menyiratkan adanya instalasi pendukung. Lapisan claystone di sekitar bangunan Sumur Putaran juga menyiratkan bahwa struktur tanah ini mendukung untuk dibangun terowongan-terowongan di bawahnya (Tim Peneliti 2014: 69-71).

Struktur bangunan seperti ini, tidak hanya ditemukan di tambang Oranje Nassau. Model bangunan seperti ini banyak ditemukan di Eropa. Beberapa bangunan memiliki bentuk yang sangat mirip dengan struktur Sumur Putaran seperti guibal fan house di tambang besi Eston dan guibal fan house Huntcliff (lihat gambar 10). Kedua bangunan tersebut terletak di Inggris, dan dibangun pada masa yang hampir bersamaan, yaitu sekitar 1870-an.

\section{Fungsi Sumur Putaran}

Berdasarkan judul pada gambar 9 , bangunan Sumur Putaran adalah rumah mesin atau gudang mesin. Namun masih belum diketahui mesin apa yang ditempatkan di dalam bangunan sumur putaran. Di dalam buku karangan Dr. Theodor
Posewitz terdapat beberapa jenis mesin yang terdapat di tambang Oranje Nassau. Mesin tersebut adalah hoisting machine, ventilator (guibal's), chain pump, dan steam pump (Posewitz 1892: 472). Kecuali steam pump yang terletak di lorong tambang paling dasar, mesin yang lain tidak dijelaskan posisi dan keletakannya.

Hoisting machine atau mesin penarik yang terdapat di tambang Oranje Nassau memiliki kekuatan 20 tenaga kuda (Posewitz 1892: 472). Pengamatan pada gambar 6 dan gambar 9 , diperoleh keterangan mengenai fungsi Sumur 2 yang terkait dengan hoisting machine. Pada gambar 9 terdapat tiang atau tali dengan posisi vertikal dari dalam sumur menuju ke atas menara yang terdapat roda di bagian atasnya. Dari roda tersebut, terdapat dua tali yang menuju bangunan dengan atap berbentuk pelana. Di dalam bangunan tersebut terdapat beberapa roda dan mesin. Dengan demikian maka, hoisting machine dapat dipastikan terletak di dalam bangunan Sumur Putaran.

Penelusuran lebih lanjut mengenai fungsi hoisting machine ini menghasilkan informasi yang cukup menarik. Informasi mengenai fungsi hoisting machine diperoleh dari buku Collieries of Wales: Engineering and Architecture (1994) yang di tulis oleh Hughes Stephen R, dkk. Dari buku tersebut dapat diketahui bahwa fungsi hoisting machine adalah untuk mengerakan headgear yang berfungsi untuk mengangkat batu bara dari lorong bawah tanah ke permukaan tanah (lihat gambar 11)

Mesin selanjutnya yang terdapat pada tambang Oranje Nassau adalah ventilator (guibal's). Mesin ventilator sering disebut dengan guibal fan. Ventilatoryang terdapat pada tambang Oranje Nassau memiliki kekuatan 5 tenaga kuda (Posewitz 1892: 472). Keberadaan mesin ventilator dalam tambang bawah tanah sangat diperlukan untuk memperlancar sirkulasi udara dan mengeluarkan gas beracun yang terdapat di dalam lorong tambang.

Dalam sebuah buku berjudul Fan and Ventilation: A Practical Guide yang ditulis oleh William Cory terdapat gambaran bermacammacam jenis mesin ventilator yang dibuat dari sekitar 1800- an sampai dengan saat ini. Di antara 


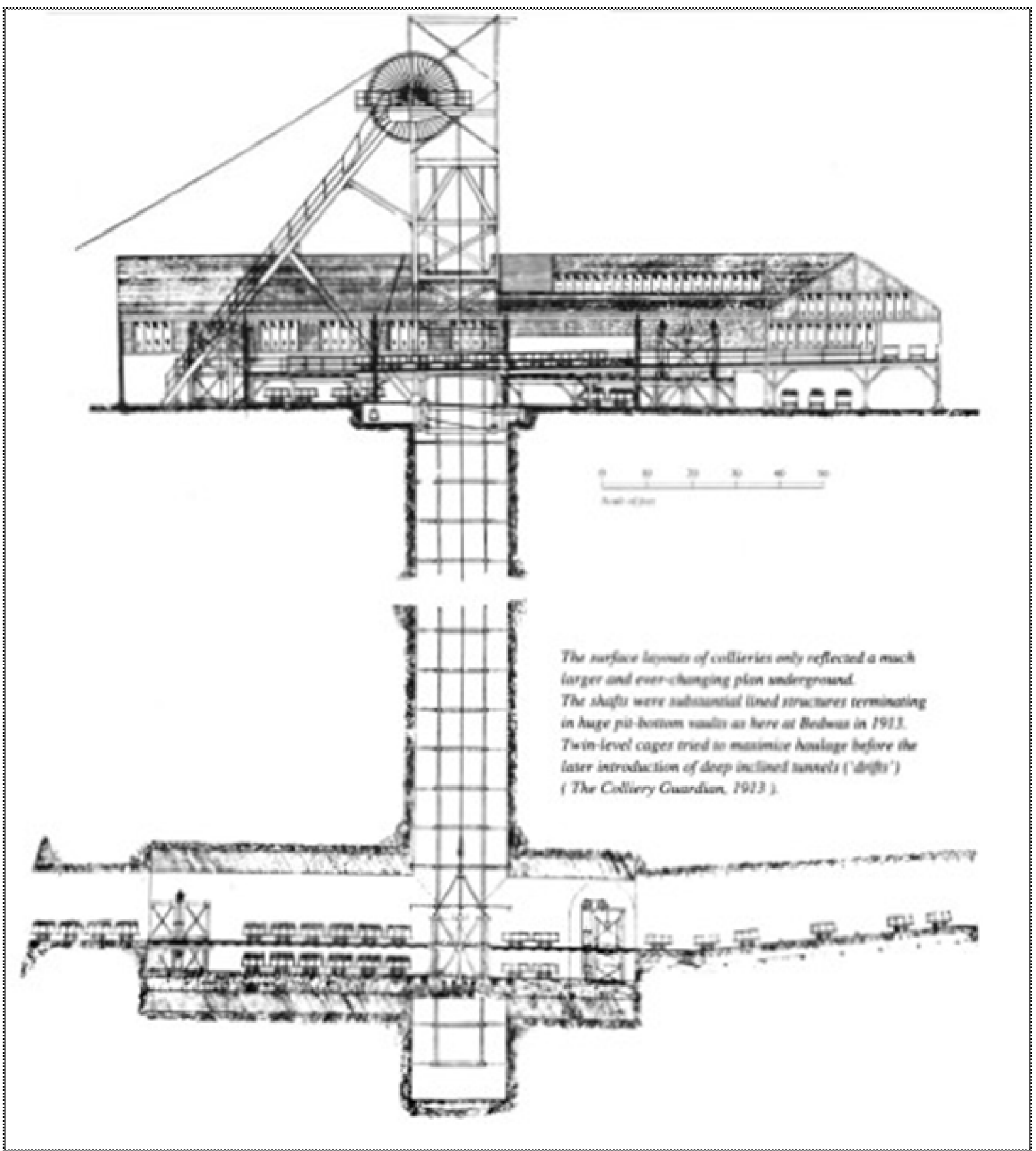

sumber: Stephen dkk. 1994: 25

Gambar 11. Hoisting machine yang digunakan untuk menggerakan headgearyang berfungsi untuk mengangkat batu bara dari dalam tahan

gambar-gambar yang terdapat di dalam buku tersebut, banyak di antaranya yang memiliki kemiripan dengan yang ada di Sumur Putaran (lihat gambar 12). Berdasarkan gambar tersebut dapat disimpulkan bahwa bangunan berbentuk kubus yang memiliki ruangan berbentuk lingkaran di dalamnya adalah tempat sebuah kipas raksasa atau disebut guibal fan. Kipas raksasa ini digerakkan oleh mesin yang sampai dengan saat ini belum diketahui keletakannya. Berdasarkan arah pergerakan kipas atau guibal fan (lihat gambar 11) maka dapat diketahui bahwa kipas ini berfungsi untuk menarik udara dari dalam tambang melalui Sumur 1.

Dua mesin yang terdapat di tambang Oranje Nassau diduga memiliki fungsi sebagai pompa. Chain pump dan steam pump memiliki fungsi yang sama, yaitu untuk menguras air dari lorong 


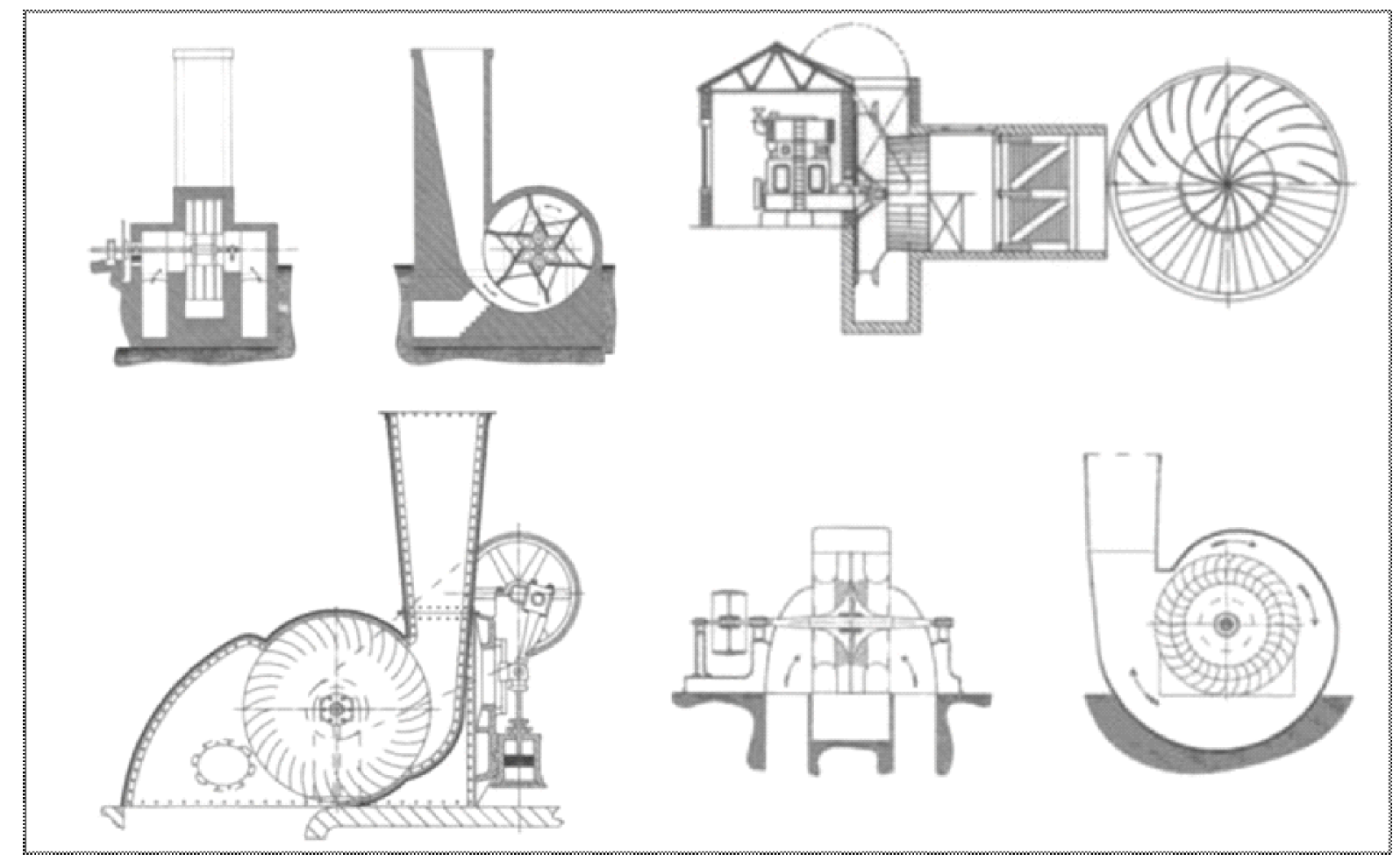

sumber: Cory 2005: 6-7

Gambar 12. Beberapa macam bentuk ventilator atau guibal fan.

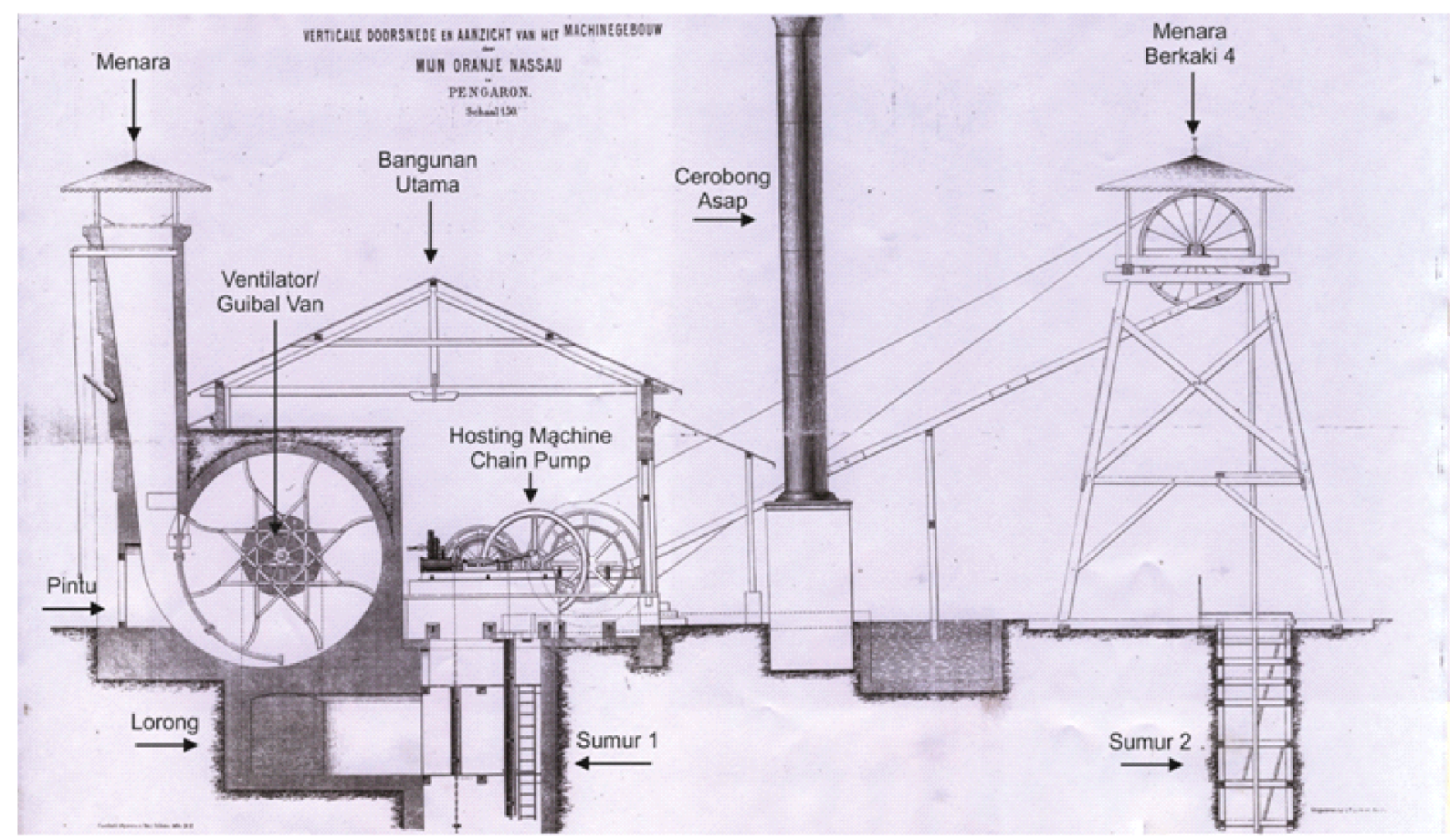

sumber: dok. ANRI dan hasil interpretasi pribadi

Gambar 13. Instalasi dan komponen Sumur Putaran, dengan beberapa keterangan setelah dianalisis melalui sumber pustaka yang dipadukan pengamatan di lapangan 
tambang di bawah tanah ke permukaan tanah. Pengurasan air ini dilakukan melalui Sumur 1. Steam pump bertugas untuk menarik air dari lorong tambang, sedangkan chain pump bertugas menarik air dari bawah ke permukaan tanah. Dalam buku DR. Theodor Posewitz, dijelaskan bahwa steam pump terletak di lorong tambang paling dasar, sedangkan lokasi chain pump tidak dijelaskan. Namun berdasarkan fungsi dari chain pump maka dapat dipastikan bahwa chain pump terletak di atas permukaan tanah (lihat gambar 13).

Pengetahuan akan bentuk asli Sumur Putaran dan fungsinya mengarahkan pada kesimpulan bahwa tambang Oranje Nassau telah menerapkan teknologi modern pada masanya. Selain itu, tambang Oranje Nassau merupakan tonggak revolusi industri di Kalimantan dengan hadirnya ketel uap sebagai penggerak untuk mengangkat air ke permukaan tanah. Tambang Oranje Nassau juga telah menerapkan prinsip keselamatan kerja dengan cara menghadirkan ventilasi udara, mengatur sirkulasi oksigen untuk pernapasan bagi pekerja dan mengurangi efek berbahaya akibat ledakan bagi para pekerjanya yang sebagian besar adalah tahanan.

\section{PENUTUP}

Fungsi dan peran Sumur Putaran dibagi menjadi beberapa bagian. Bagian utama adalah rumah berbahan baku kayu dengan atap berbentuk pelana. Di dalam bangunan ini terdapat ruangan berbentuk kubus. Di dalam bangunan kubus ini terdapat ruangan berbentuk lingkaran yang terhubung dengan menara. Pada bagian bawah ruangan berbentuk kubus ini terdapat lorong yang terhubung dengan Sumur 1. Di bagian luar bangunan utama ini terdapat cerobong asap. Di dalam bangunan utama terdapat Sumur 1. Selain bangunan utama, terdapat menara kayu berkaki empat dengan atap limasan. Menara ini terletak tepat diatas Sumur 2. Pada bagian puncak menara ini terdapat roda. Roda ini terhubung dengan tali dengan mesin yang terletak di dalam bangunan utama.

Fungsi bangunan Sumur Putaran adalah sebagai gudang atau rumah mesin. Di dalam kompleks Sumur Putaran terdapat beberapa mesin yang berfungsi sebagai alat untuk mengangkut batu bara dari dalam tanah sampai ke permukaan tanah yang disebut hoisting machine. Di dalam bangunan Sumur Putaran juga terdapat kipas besar yang disebut ventilator atau guibal fan berserta dengan mesin penggeraknya yang berfungsi memperlancar udara di dalam tambang dan juga mengeluarkan gas beracun. Selain itu, juga terdapat mesin yang berfungsi untuk mengangkat air dari dalam tambang ke permukaan tanah yang disebut chain pump.

\section{DAFTAR PUSTAKA}

Ahyat, Ita Syamtasiyah. 2012. Kesultanan Benjarmasin pada abad ke-19 Ekspansi Pemerintah Kolonial di Kalimantan. Tangeran Selatan : Serat Alam Media

ANRI. 1872. Jaarboek van Het Mijnwezen in Nederlandsch Oost Indie. Batavia : Landsdrukkerii.

Cantril, T.C. I. 1914. "Coal Mining" Diunduh 1 Oktober 2014 (www.forgotten books.org).
Circa. 1900. "Meeroever bij Pengaron,Borneo". Diunduh 21 Januari 2016 (http://mediakitlv.nl/all-media/indeling/detail/form/ a d $v$ a $n$ c e d d / s t a $r$ t l 1?q_searchfield=pengaron).

Cory, William. 2005. Fan and Ventilation: $A$ Practical Guide. Elsevier Science: New York. 
Czn, Stemler. 1893 "Pengaron". Diunduh 21 Januari 2016 (http://media-kitlv.nl/all-medial indeling/deta il/form / advanced?q_searchfield=pengaron).

Dorp, H.M. van. 1861. "Pengaron". Diunduh 21 Januari 2016 (http://media-kitlv.nl/all-media/ indeling/detail/form/advanced/start/ 7?q_searchfield=pengaron).

Garratt, Mick. 2006. "Ruins of Fan House, Huntcliff Ironstone Mine". Diunduh 30 September 2016 (http://www.geograph.org.uk/photo/ 164166).

Hooze, J.A. 1893. "Kolenontginning te Pengaron: aan de rivier Riam Kiwa (diepbouw)". Diunduh 21 Januari 2016 (http://www.mediakitlv.nl/all media/indeling/detail/form/ a d $v$ a $n$ c e d / s t a r t / 4?q_searchfield=pengaron).

Lindblad. 2012. Antara Dayak dan Belanda. Malang: Lilin Persada Press.

Prastowo, Andi. 2014. Metode Penelitian Kualitatif dalam Perspektif Rancangan Penelitian. Sleman: Ar-Ruzz Media

Posewitz, Theodor. 1892. Borneo its Geology and Mineral Resource. London: Edward Stanford.

Pollard, Rob. 2005. "Guibal Fan House". Diunduh 30 September $2016 \quad$ (http:// www.geograph.org.uk/photo/24980)

Saleh, Idwar. 1979. Studi mengenai Peranan Pengeran Antasari Dalam Perang Banjar 1859-1865. Banjarmasin: Universitas Lambung Mangkurat Fakultas Keguruan.

Sjarifudin, H, dkk. 2007. Sejarah Banjar. Banjarmasin: Badan penelitian dan Pengembangan Daerah Provinsi Kalimantan Selatan.
Susanto, Nugroho Nur. 2015. "Model Pertambangan Batu bara Oranje Nassau Pengaron Memberi Inspirasi Penyelamatan Kawasan Pegunungan Meratus". HIm. 206216 dalam Budaya di Kawasan Pegunungan Meratus Dalam PerspektifArkeologi, editor Bambang Sulistyanto. Banjarbaru: Balai Arkeologi Banjarmasin.

Stephen R. Hughes, Malaws, Brian, Parry, Medwyn, dan Peter Wakelin.1994. Collieries of Wales: Engineering and Architecture. Wales: Royal Commision on the Ancient and Historical Monument of Wales.

Tim Peneliti. 2012. "Laporan Penelitian Arkeologi Situs pengaron, Kabupaten Banjar, Provinsi Kalimantan Selatan". Laporan Penelitian Arkeologi. Banjarbaru: Balai Arkeologi Banjarmasin.

Tim Peneliti. 2014. "Penelitian Tambang Batu bara Oranje Nassau, Pengaron Tahap II Kabupaten Banjar Provinsi Kalimantan Selatan". Laporan Penelitian Arkeologi. Banjarbaru: Balai Arkeologi Banjarmasin.

Tim Penyusun. 1995. Kamus Besar Bahasa Indonesia. Jakarta: Balai Pustaka.

Tropenmuseum. Tanpa tahun1. "De plaats Pengaron". Diunduh 22 Januari 2016 (http:/ /www.geheugenvannederland. $\mathrm{nl} /$ ?/nl/ i t e m s/K I T 0 1:100711/ \&p=1\&i=1\&t=2\&st=pengaron\&sc=\%28pengaron\%29/ \&wst=pengaron).

Tropenmuseum. Tanpa tahun2. "Het dorp Pengaron". Diunduh 22 Januari 2016 (http:/ /www.geheugenvannederland.nl/?/nl/ $\mathrm{item} \mathrm{s/KIT01:100739/}$ $\& \mathrm{p}=1 \& \mathrm{i}=2 \& \mathrm{t}=2 \& \mathrm{st}=$ pengaron\&sc=\%28pengaron $\% 29 /$ \&wst=pengaron). 